Int. J. Odontostomat.,

4(2):123-126, 2010.

\title{
Open Access in Chilean Dentistry Journals
}

\author{
Acceso Abierto en las Revistas Chilenas de Odontología
}

Ricardo Cartes-Velásquez

CARTES-VELÁSQUEZ, R. Open access in Chilean dentistry journals. Int. J. Odontostomat., 4(2):123-126, 2010.

\begin{abstract}
Open Access (OA) has become a topic of interest and development in the world of scientific publications, especially in biomedicine area, driven by the precepts of free access to information and cooperation that results in improvement of people quality of life. The aim of this study is to evaluate the state of Chilean dentistry journals regarding OA. Included all Chilean scientific dental publications indexed in LATINDEX, evaluated variables free access to full articles, access to previous volumes, easy and intuitive access, publisher and presence in PubMed, LILACS, SciELO and / or Google Scholar index. 19 publications was founded of which 58\% (11) had free access to full articles, 2 allowed independent access to each paper, 6 had access to their previous volumes in an orderly and 4 with some limitation and / or disorder, regarding to publisher: 3 have own websites and 8 were associated with institutional websites. With regard to indexing: 5 were in Pubmed and 6 in LILACS, but none currently. $58 \%$ of the publications studied showed OA. Only 1 publication maintained high standards of OA. No presence in specialized platforms like SciELO or Google Scholar.
\end{abstract}

KEY WORDS: open-access, dentistry journals, Chile.

\section{INTRODUCTION}

Open Access (OA) is defined, according to the Budapest Declaration, as an editorial model where the access to scientific literature and their use are free (Sanchez-Martin et al., 2009). There are basically 2 ways in which $O A$ is implemented: the first is the greenroad where the papers that have been published under a traditional model or others articles that the author wants to publish are made available through repositories, and second is the gold-road in which the articles are published in OA specific journals (Harnard, 2004; Kuhlen, 2007). In both roads the Internet becomes the platform in which the OA is implemented.

Numerous studies have been conducted on this subject, particularly on the impact it has on the diffusion of science and which is recognized as the major benefit of the model (Chesler, 2004) as well a greater impact that achieve the articles published under this model (Hajjem et al., 2005), improvement in the visibility of the gray literature and scientific output of the least developed countries (Hajar \& Abbas, 2008) and greater empowerment of authors and funding institutions on the ownership and dissemination of their research (Glover et al., 2006). However some of these benefits have not been sustained over time (Bosch, 2009; Davis, 2009; Craig et al., 2007; Anderson, 2004) and have questioned the real contribution of the model.

Other considerations in this regard are the economic losses that brings the $\mathrm{OA}$ to publisher companies that traditionally were in charge of the editorial process (Morris, 2004), and the particular impact they have in the field of biomedicine on the application of treatments published in OA journals (Hardisty \& Haaga, 2008) compared to the traditional model.

Thus it is that currently it is concluded that while $O A$ is a beneficial model is not a panacea for the diffusion of science. In the field of biomedicine, however, have found more advantages and a growing-up adoption of the model (Matsubayashi et al., 2009; Liesegang et al., 2005).

The aim of this study is to assess various aspects of the implementation of OA by Chilean dentistry journals. In literature there is no specific research on this topic applied to our profession, so this article is a pioneer in this field. 


\section{MATERIAL AND METHOD}

Was performed a descriptive cross-sectional study in all scientific journals of dentistry in Chile, the list of such publications was obtained by a exhaustive manual revision from information supplied by the LATINDEX database, updated to October 2009, it was choosed a manual revision due to a lack of "dental journals item" in this database clasification and the great variability in the titles of chilean dentistry journals what made difficult and improductive do a search by $\mathrm{MeSH}$ or keywords. 19 publications were founded (Table I) to which the following features were assessed in relation to OA:

Free access to full-articles: In the last issue edited and regardless of the format available.

Access to previous volumes.

Order: Expeditious and intuitive access to the articles and volumes.

Publisher: The institution in charge and the web platform used.

Database index: The presence in the databases Pubmed, LILACS, SciELO and / or Google Scholar.

Data tabulation was done in spreadsheet software MS Excel 2003.

\section{RESULTS}

$11(59 \%)$ of the 19 publications assessed had free-access to full-articles of its last issue, mainly in PDF format, but only $2(11 \%)$ allow a independent review of each article.

In regard to the possibility of review previous volumes, a total of 10 journals permitted $(53 \%)$ but only 6 of them (32\%) in anorderly and expeditious way.

Regard to the publisher and the platform used, 3 $(16 \%)$ had their own web sites and $8(42 \%)$ were associated with their responsible institutions, especially scientific societies.

Finally in the evaluation of free access databases indexing were founded $5(26 \%)$ in PubMed and 6 (32\%) in LILACS, but none was present currently; no presence in specialized platforms like SciELO or Google Scholar. DISCUSSION

Although in comparison to similar studies in the field of biomedicine (Matsubayashi et al.) the above results can be considered favorable with an implementation of $\mathrm{OA}$ in $58 \%$ of publications, a finer analysis of the situation shows a less positive about this

Chilean Dentistry Journals. (LATINDEX, October 2009)

Revista Dental de Chile
Odontologia Chilena
Revista de la Sociedad Chilena de Odontopediatría
Canal Abierto
Revista Clíni ca de Periodoncia, Implantología y Rehabilitación Oral
Anuario de la Sociedad de Radiología Oral y Máxilo Facial de Chile
Esencia odontológica
International Journal of Odontostomatology
Magazine - International College of Dentists. Section IV
Mundo dental (Santiago)
Revista chilena de odontoestomatol ogía
Revista chilena de ortodoncia
Revista chilena de periodoncia y oseointegración
Revista de la Facultad de Medicina y Odontología - Universidad de Antofagasta
Revista de la Facultad de Odontología de la Universidad de Chile
Revista de la Facultad de Odontología de la Universidad de Concepción
Revista de la Facultad de Odontología (Valparaíso)
Revista - Sociedad de Prótesis Estomatológica de Chile
Salud oral - bioética


model in the Chilean dentistry. This is confirmed if we take into account the objectives pursued by the model: free access and use of scientific articles, to which we must add a third: order.

If we consider the "order" factor, defined as an expeditious and intuitive access to the articles and previous volumes independently then only 1 publication, International Journal of Odontostomatology, reach the high standards of gold-road of OA model. This is important because these standards are those that support proper dissemination of information in articles, on the contrary a messy website, without the possibility of access to individual articles or files that exceed 4 megabytes become barriers that discourage potential readers and thus have prevented dissemination, although the articles are freely available.

Another point of importance is the appearance of specialized platforms that host a set of journals under OA model, the more remarkable: SciELO, Google Scholar and J-STAGE, as well the DOAJ Directory. These platforms strengthen and broaden the visibility of their publications and therefore the impact of the articles they publish (Matsubayashi et al.). Unfortunately none of the reviewed publications was present in some of these platforms. But not only these platforms have the potential to offer free, orderly and with high standards contents of an OA-journal that increase their visibility, there is also the possibility of implementing them individually for example through the OJS system (SINAB, 2008) and that is the same implemented by SciELO, system for management of entire editorial process.

$\mathrm{OA}$ in the world is a growing trend, especially in the field of biomedicine where facilitate diffusion of new developments in a free and fast way what achieved equity in access to information resulting in improved quality of life of people in equal terms. The former is perhaps the biggest advantage of this model in our area, however, other initial advantages over the traditional publishing model like a increased citation and impact of OA articles and the recognition of scientific production in undeveloped countries or third world in these past years have disappeared completely (Bosch; Davis; Hajar \& Abbas) so that there is no difference between $\mathrm{OA}$ and non-OA journals. To this we must add that there are disincentives to the authors for publishing in OA journals that are less prestige principle of their paid counterparts (Hernandez-Borges et al., 2006; Anderson) that becomes a barrier to apply the model.

Despite the above there is models as SciELO that have been successful and grow year after year, increasing its international visibility and citation impact (Menghini et al., 2006) and have become the perfect complement to the scientific production in Latin America and especially Brazil. This is basically due to government support and the existence of genuine and effective policies in the stimulation of science and research, including the OA model present in SciELO.

All this bring to us important lessons about what to expect and how it should be implemented and maintained this model, to obtain positive results and comparative advantages over the traditional publishing model, but mainly as a tool for stimulating scientific research and production.

Finally returning to the study results and considering the international experience, we can see that $\mathrm{OA}$ is a real opportunity to improve the scenario as far as Chilean dental science is concerned, but should improve the way they are applying, ideally fulfill with high standards of gold-road, have the institutional support and government policies in the search for significant and long term results.

CARTES-VELÁSQUEZ, R. Acceso abierto en las revistas chilenas de odontología. Int. J. Odontostomat., 4(2):123-126, 2010.

RESUMEN: El acceso abierto (AA) se ha convertido en un tema de interés y desarrollo en el mundo de las publicaciones científicas, especialmente en el área biomédica, impulsado por los preceptos de acceso libre a la información y cooperación que redunde en el mejoramiento de la calidad de vida de las personas. El objetivo de este estudio es evaluar como se encuentran las publicaciones científicas odontológicas chilenas con respecto al AA. Se incluyeron todas las publicaciones científicas odontológicas chilenas indexadas en LATINDEX, en ellas se evaluaron las variables: libre acceso a artículos completos, acceso a volúmenes anteriores, acceso expedito e intuitivo, plataforma de publicación y presencia en los índices Pubmed, LILACS, SciELO y/o Google Scholar. Se encontraron 19 publicaciones de las cuales el 58\% (11) presentaron libre acceso a artículos completos, 2 permitían el acceso independiente a cada artículo, 6 tenían acceso a sus volúmenes anteriores de forma ordenada e intuitiva y 4 con alguna limitación y/o desorden, en cuanto a la plataforma de publicación 3 tenían webs dedicadas o propias y 8 estaban asociadas a webs institucionales. Ninguna publicación se indexa actualmente en las plataformas estudiadas, pero 5 lo hicieron en Pubmed y 6 en LILACS. El 58\% de las publicaciones estudiadas presentaban AA. Solo 1 publicación mantenía altos estándares de AA. No existe presencia en plataformas especializadas como SciELO o Google Scholar.

PALABRAS CLAVE: acceso abierto, revistas odontológicas, Chile. 


\section{REFERENCES}

Anderson, R. Author disincentives and open acces. Serial Reviews, 30(4):288-91, 2004.

Bosch, X. A reflection on open-access, citation counts, and the future of scientific publishing. Arch. Immunol. Ther. Exp., 57:91-3, 2009.

Chesler, A. Open acces: A review of an emerging phenomenon. Serials Review, 30(4):292-7, 2004.

Craig, I; Plume, A; MacVeigh, M; Pringle, J \& Mayur, A. Do open access articles have greater citation impact? A critical review of the literature. J. Informetrics, 1:239-48, 2007.

Davis, P. Author-Choice Open-Access Publishing in the Biological and Medical Literature: A Citation Analysis. J. Amer. Soc. Infor. Sci. Tech., 60(1):3-8, 2009.

Glover, S; Webb, A \& Gleghorn C. Open access publishing in the biomedical sciences: could funding agencies accelerate the inevitable changes? HIth. Infor. Libr. J., 23:197-202, 2006.

Hajar, S \& Abbas, H. Great expectations: The role of Open Access in improving countries' recognition. Scientometrics, 76(1):69-93, 2008.

Hajjem, C; Harnad, S. \& Gingras, Y. Ten-year crossdisciplinary comparison of the growth of open access and how it increases research citation impact. IEEE Data Eng. Bull., 28(4):39-47, 2005.

Hardisty, D \& Haaga, D. Diffusion of Treatment Research: Does Open Access Matter? J. Clin. Psychol., 64(7):82139, 2008.

Harnard, S.; Brody, T.; Vallieres, F.; Carr, L.; Hitchcock, S.; Gigras, Y.; Oppenheim, C.; Stammerjohanns, H. \& Hil, E. The Access/Impact Problem and the Green and Gold Roads to Open Access. Serials Review, 30(4):310-4, 2004.

Hernandez-Borges, A.; Cabrera-Rodriguez, R.; Montesdeoca-Melian, A.; Martinez-Pineda, B.; TorresAlvarez, M. \& Jimenez-Soza, A. Awareness and attitude of Spanish medical authors to open access publishing and the "author pays" model. J. Med. Libr. Assoc., 94(4):449-51, 2006.

Kuhlen, R. Open access: un cambio de paradigma para la puesta a disposición pública del conocimiento. El desarrollo en Alemania. BiD, 18(1), 2007.

Liesegang, T; Schachat, A. \& Albert, D. The Open Access Initiative in Scientific and Biomedical Publishing: Fourth in the Series on Editorship. Am. J. Ophthalmol., 139(1):156-67, 2005.

Matsubayashi, M.; Kurata, K.; Sakai, Y.; Morioka, T.; Kato, S.; Mine, S. \& Ueda, S. Status of open access in the biomedical field in 2005. J. Med. Libr. Assoc., 97(1):411, 2009

Morris, S. Open Access: How Are Publishers Reacting? Serials Review, 30:304-7, 2004.

Meneghini, R.; Mugnaini, R. \& Packer, A. International versus national oriented Brazilian scientific journals. A scientometric analysis based on SciELO and JCR-ISI databases. Scientometrics, 69(3):529-38, 2006.

Sánchez-Martín, F.; Millan, F. \& Villavicencio, H. La iniciativa Open-Access (OAI) en la literatura cientifica. Act. Urol. Esp., 33(7):732-40, 2009.

SINAB. Manual de Usuario de OJS. Sistemas de Bibliotecas de la Universidad Nacional de Colombia, 2008.

Dirección para correspondencia:

Ricardo Cartes-Velásquez

Villa Ralco s/n, Alto Biobio.

CHILE

Telefono: $56-43-333822$

Email: cartesvelasquez@gmail.com

Recibido : 22-11-2009

Aceptado: 21-04-2010 